\title{
Key factors affecting the technical efficiency of bee farms in the province of La Pampa (Argentina): A two-stage DEA approach
}

\section{Factores clave que afectan la eficiencia técnica de las granjas apícolas en la provincia de La Pampa (Argentina): un enfoque DEA en dos etapas}

\author{
Elena Angón ${ }^{1}$, Tomás Bragulat ${ }^{2}$, Antón García ${ }^{1 *}$, Alberto Giorgis ${ }^{2}$, José Perea ${ }^{1}$
}

Originales: Recepción: 07/10/2019 - Aceptación: 17/02/2021

\begin{abstract}
This paper analyzes how decision-making, management capacity and technology adoption by beekeepers, affect the technical efficiency (TE) of Argentinean beekeeping through the case study of the province of La Pampa (Argentina). The assessment of TE is currently receiving ever-growing attention as an indicator of sustainability and usage of sufficient natural resources in beekeeping activities. This study aimed to identify the key factors affecting the technical efficiency of bee farms in the province of La Pampa. The study included a sample of 40 bee farms and estimated their TE score through an input-oriented Data Envelopment Analysis (DEA) model. In a second stage, Tobit regression was determined to evaluate the technical inefficiency determinants. This paper found that most beekeeping production units have low TE levels. Only $25 \%$ of bee farms produce either at or close to the frontier. The Tobit model revealed that variables such as marital status, educational level, primary family income, source information usage, planning and health area, affect positively on pure technical efficiency. These results are considered to be of great interest for structured beekeeping systems on small-scale and family farms, as well as for political decision-makers, regarding a public program in apiculture.
\end{abstract}

\section{Keywords}

sustainability $\bullet$ bee farm management $\bullet$ decision-making $\bullet$ DEA $\bullet$ Tobit model

1 Universidad de Córdoba. Departamento de Producción Animal. Crta. Madrid-Cádiz. km. 396-a. 14071. Córdoba. Spain. * pa1gamaa@uco.es

2 Universidad Nacional de La Pampa. Facultad de Ciencias Veterinarias Calle 5 Esq. 116. 6360. General Pico. Argentina. 


\section{RESUMEN}

En este documento se analiza cómo la toma de decisiones, la capacidad de gestión y el nivel de adopción tecnológica por parte de los apicultores, afectan a la eficiencia técnica (ET) de la apicultura argentina a través del estudio de caso de la provincia de La Pampa. La evaluación de la ET está recibiendo una atención cada vez mayor como un indicador de la sostenibilidad, así como en el uso adecuado de los recursos naturales en las actividades apícolas. El objetivo de este estudio fue identificar los factores clave que afectan a la eficiencia técnica de las explotaciones apícolas de la provincia de La Pampa. El estudio incluyó una muestra de 40 unidades apícolas situadas en la provincia de La Pampa para estimar su nivel de ET mediante la metodología de Análisis de la Envolvente de Datos (DEA) orientado a los inputs. En una segunda etapa se empleó la regresión Tobit para evaluar los factores determinantes de la ineficiencia. En este trabajo se comprobó que la mayoría de las unidades de producción apícola tienen niveles bajos de ET. Solo el 25\% de las unidades apícolas producen en la frontera de producción o cerca de ella. El modelo Tobit reveló que variables como, estado civil, nivel educativo, principal fuente de ingresos familiares, uso de información, planificación y el área de salud, son las que afectan positivamente a la ET pura. Estos resultados se consideran de interés para los sistemas apícolas de pequeña escala y familiares, y pueden resultar útiles para los responsables de las políticas sobre un programa público de apicultura.

\section{Palabras clave}

sostenibilidad $\bullet$ manejo de la granja apícola $\bullet$ toma de decisiones $\bullet$ DEA $\bullet$ modelo Tobit.

\section{INTRODUCTION}

The Food and Agriculture Organization of the United Nations (FAO) has the commitment to eradicate hunger and reduce poverty in the world by ensuring food security and improving livelihoods. Besides, FAO has five strategic objectives, one of them being to "Make agriculture, forestry and fisheries more productive and sustainable", likewise including a more productive, sustainable, and efficient apiculture (20).

Argentinian beekeepers own over 3.5 million beehives distributed by 30,000 production units, which produce more than 80,000 t per year, with an income of 180 million US\$ the last year by international trade. Thus, Argentina is the leading country in America, exporting honey wordwide (32). An insufficiently developed domestic consumer market, favourable monetary exchange rates and the existence of official traceability schemes to guarantee the quality of the final product, are factors contributing to this scenario (21). Moreover, ecological conditions prevailing in Argentina ensure the availability of flowers from wild species and cultivated plants. Production of honey is concentrated in the Pampean region, contributing $70 \%$ of the total production in Argentina (47).

In the last years, various approaches to decision-making and managerial capacity have been widely used to quantify and compare the performance of agricultural and livestock systems $(34,36,38,39,51,53)$. Furthermore, the concept of efficiency has been awidely used tool for evaluating technical and economic success $(6,7,15,29,41)$. So far, several studies have been carried out on beekeeping all over the world. Some researchers have focused on the technical side of beekeeping, while the rest have been interested in the economic dimension of this activity $(2,3,42)$. However, the studies focused at a beekeeper level have been rare all over the world since the process of collecting information requires more time (12). Some researchers have focused only on production indicators by ignoring the details of data management. Relatively few researchers have studied some aspects using detailed data management at a beekeeper level $(28,33,46)$. It is noteworthy that Lema and Delgado (2000) investigated the sources of technical efficiency (TE) including decision-making and managerial capacity variables in producers from the province of Buenos Aires. Besides, Bragulat et al. (2018) studied the influence of decision-making and managerial capacity of La Pampa honey producers in the economic feasibility. The well-fitting regression model was constructed with variables related to decision-making knowledge and evaluated the principal lack of beekeepers in the management of their productive units. 
A key indicator of resource optimisation within farming systems is the assessment of TE, which measures the amount of physical output attainable from a given set of inputs. The approaches estimating TE are divided into two methodologies: the parametric methods, including the construction of stochastic (8) or deterministic $(6,51,52)$ frontier models; and non-parametric methods. Recently, the measurement of productive efficiency with the non-parametric approach has used the Data Envelopment Analysis (DEA) method. DEA involves linear programming to calculate the frontier of an economic unit and identify the proportion of inputs with the maximum efficiency, or the portion of maximum output with the limited inputs $(7,28)$. DEA developed by Charnes et al. (1978), has also been widely used to estimate the TE score of livestock (13).

Using this procedure, the most efficient beekeeping production unit in a sample can be used as the main reference to measure the relative efficiency of each unit and to determine the causes of inefficiency. This approach, commonly used in economics, has proven to be useful when evaluating livestock production systems. Therefore, its application to a system such as beekeeping could lead to better knowledge for the improvement of sustainability on bee farms. Based on this background, our study aimed to identify the key factors affecting the technical efficiency of beekeeping production units of La Pampa (Argentina). The method was based on a two-stage analysis approach, with productivity measures derived in the first stage using input-orientated DEA. In the second stage of the analysis, the influence of apiarist managerial capacity and farmer decision-making on the derived efficiency was examined through the Tobit regression model. It is worth to note that this study is the first to apply the DEA method of apiculture sector in Argentina. Understanding this issue will be beneficial for planning actions to alleviate inefficiency and to improve the agricultural production efficiency in Pampean beekeeping.

\section{MATERIAL AND METHODS}

\section{Study area and data collection}

The study was carried out in the province of La Pampa in Argentina, which is composed of 1,500 bee farms, distributed in four of the province's 22 administrative departments (45). La Pampa is located in the geographic centre of Argentina and covers an area of about $143,440 \mathrm{~km}^{2}$ (approximately $5.2 \%$ of the country). The soil, which shows a slight slope towards the East, and mild undulations from North to South, is constituted by sandy sediments, ranging from $1 \mathrm{~m}$, in the West, to over $6 \mathrm{~m}$ depth in the East, with no rocky patches (27). The climate of the area is characterized by mild winters and summers, with seasonal rains during the spring. The average annual precipitation and temperature are $724 \mathrm{~mm}$ and $15^{\circ} \mathrm{C}$, respectively.

According to Milán et al. (2011), a randomized sampling design, stratified per department with proportional allotment, was used ( 0.95 confidence level, 0.1 precision and 0.5 estimated true proportions). The selected sample comprised 40 bee farms (which constituted a $5.3 \%$ of the studied population) and included beekeepers ready to provide information.

Information related to management was obtained by direct interviews with the apiarist or the manager, and by direct observation on farms during the period 2011-2013. This was based on the methodology described by Perea-Muñoz et al. (2011), which was appropriately adapted to beekeeping.

Information that was gathered from the questionnaire included 18 management variables, which were defined under the hypothesis that they may explain differences in farm technical inefficiency. In a similar way, Perea et al. (2014), studied the effect of management variables in dairy farm viability. Management variables used are shown in table 1 (page 153).

Nine variables were selected to represent the influence of the apiarist personal aspects (table 1, page 153): family size, civil state, age, experience, educational level, personnel training, continuity of activity, primary source of family income and primary source of income for the apiarist. The influence of the decision-making process was studied through nine variables representing two aspects: access and use of information by the manager, and the formality of the process. 
Table 1. Definition of variables as influencing technical efficiency of bee farms.

Tabla 1. Definición de variables que influyen en la eficiencia técnica de las explotaciones apícolas.

\begin{tabular}{|c|c|}
\hline Variable & Definition \\
\hline \multicolumn{2}{|r|}{ Apiarist's personal aspects } \\
\hline Family size (FS) & Number of family members \\
\hline Civil state $(\mathrm{CS})$ & Dummy = 1 If the producer is married or divorced, 0 if he is single \\
\hline Age $(\mathrm{A})$ & Manager age \\
\hline Experience $(\mathrm{E})$ & Number of years of managerial experience \\
\hline Educational level (EL) & Dummy = 1 If it is secondary or higher, 0 if it is primary level. \\
\hline Personnel training (PT) & Dummy = 1 If it is has taken beekeeping courses, 0 if there is not \\
\hline Continuity of activity (CA) & Dummy = 1 If it is continuing with the long-term activity, 0 if there is not \\
\hline Primary source of family income (PSF) & Dummy = 1 if only beekeeping, 0 if there are another source of family income \\
\hline Primary source of apiarist income (PSA) & Dummy = 1 if only beekeeping, 0 if there are another source of apiarist income \\
\hline \multicolumn{2}{|r|}{ Decision-making process } \\
\hline Record (R) & Dummy = 1 If data are periodically recorded, in an organized manner, 0 if there is not \\
\hline Record use (RU) & Dummy = 1 If records are used formally, 0 if there is not \\
\hline Information use (IU) & Dummy = 1 If external information is used, 0 if there is not \\
\hline Economic advisors (EA) & Dummy $=1$ If periodic economic advisers are available, 0 if there is not \\
\hline Technical advisors (TA) & Dummy $=1$ If periodic technical advisers are available, 0 if there is not \\
\hline Associationism (As) & Dummy $=1$ If the production unit is integrated in some producers' association, 0 if there is not \\
\hline Objective $(0)$ & Dummy $=1$ If there is a clear a consistent planning with corporate aims, 0 if there is not \\
\hline Planning (P) & Dummy = 1 If there are ongoing plans coherent with the objectives, 0 if there is not \\
\hline Evaluation (E) & $\begin{array}{l}\text { Dummy = } 1 \text { If the objectives in the assessment procedure used by the manager to evaluate the } \\
\text { outcome of his plans, } 0 \text { if there is not }\end{array}$ \\
\hline \multicolumn{2}{|r|}{ Technologies adoption level } \\
\hline Equipment area (\% T1) & Percentage of technologies that maximize the use of the infrastructure \\
\hline Health area (\% T2) & $\begin{array}{l}\text { Percentage of technologies that allow to mitigate the risks associated with animal health, and } \\
\text { enhance and guarantee the quality of the products }\end{array}$ \\
\hline Feeding area (\% T3) & Percentage of technologies that identify and optimize the feeding system \\
\hline
\end{tabular}

The information obtained by the manager was studied through the following variables: records, economic advisors, technical advisors and associationism. Regarding the use of information, apiarists were asked to classify it in each of the provided sources. The usage of records and information involves variables indicate the regular use of the archives, and the frequent use of external information sources, respectively. The formality of the decision-making process was evaluated according to three aspects: objective, planning and evaluation. The apiarists were requested to describe the goals of their business, their ongoing plans and whether if they knew their programmes worked. 
Furthermore, technology adoption level was analysed (table 1, page 153). To do this, three variables that indicate the level of adoption in the main technological areas, were evaluated. These technological areas were equipment (\% T1), health (\% T2) and feeding (\% T3). Each area has a set of technologies and innovations allocated called items. The technological area indicates the proportion of the items adopted by each production unit over the total of items assigned in the area. Identification of technologies and innovations relevant to the apicultural system and their allocation in areas, was achieved through a participatory process of discussion and consensus, following the methodology described by García-Martínez et al. (2016). A similar procedure was applied by Freitas et al. (2004) to evaluate the technological level of beekeeping in Brazil. The equipment area comprised six items: basic beekeeping facility, basic apiculture machine, basic beekeeping equipment, honey extraction capacity, honey collection capacity and wax melting capacity. The health area included seven items: disease prevention program, ability to diagnose pathologies, antiparasitic rotation, and application of routine treatments against Varroasis, American foulbrood, European foulbrood and Nosemosis. Finally, the feeding area consisted of five items: winter feeding, protein supplementation, productive incentive, transhumance of hives and queens rearing.

\section{Data Envelopment Analysis and Tobit regression analysis}

Data Envelopment Analysis (DEA), a non-parametric method, whose was first proposed by Farrell (1957) and then improved by Charnes et al. (1978), has become a popular tool for measuring the technical efficiency of larger application field. In economics, a decision-making unit (DMU) is considered to refer to an individual or entity. Thus, DEA measures the efficiency of each DMU relative to that frontier, attributing all observed deviations from that frontier to inefficiencies. DMU is a commonly used term in DEA analysis, and it corresponds to a bee farm in La Pampa Province.

DEA model needs an orientation, either input or output-oriented. Pampean beekeepers tend to have greater control over their inputs than they have over their output. For that reason, an input-oriented model was applied in order to reduce the inputs. DEA model was constructed by 40 DMU of the sample considering one output and four inputs. Table 2 shows the output and inputs, their units, means, standard deviations and coefficient of variation. The output used was honey production (kg/year) as the main product coming from bee farms. According to our literature review, the chosen inputs were investment (ARS), the number of hives, feed cost (ARS/year) and labour cost (ARS/year).

Table 2. Descriptive statistics of the inputs and outputs used to estimate technical efficiency.

Tabla 2. Estadísticas descriptivas de insumos y productos utilizados para estimar la eficiencia técnica.

$1 \mathrm{USD}=4,4$ Argentinian pesos (ARS). $1 \mathrm{USD}=$ Pesos argentinos (ARS).

\begin{tabular}{|c|c|c|c|c|}
\hline Variable & Mean & Standard deviation & Minimum & Maximum \\
\hline \multicolumn{5}{|c|}{ Output } \\
\hline Honey production (kg/year) & $7,398.75$ & $13,745,53$ & 30 & 56,000 \\
\hline \multicolumn{5}{|c|}{ Inputs } \\
\hline Investment (ARS) & $276,645.87$ & $401,566.79$ & 17,200 & $1,819,550$ \\
\hline Number of hives & 339.75 & 477.30 & 20 & 2,000 \\
\hline Feed costs (ARS/year) & $2,901.62$ & $4,775.67$ & 0 & 18,000 \\
\hline Labour costs (ARS/year) & $3,894.5$ & $9,928.06$ & 0 & 54,000 \\
\hline
\end{tabular}

The number of DMUs has an essential impact on the degree of freedom; Cooper et al. (2011) provided a rough rule to solve this problem in the DEA model. The recommendation is to select a value of $n$ that satisfies $n \geq\{m \times s ; 3(m+s)\}$ where $n$ is the number of DMUs, $m$ is the number of inputs, and $s$ is the number of outputs. Therefore, the number of DMUs in our sample satisfies the rule in this study. 
The data for all bee farms were represented by the $\mathrm{K} \times \mathrm{N}$ input matrix $(\mathrm{X})$ and $\mathrm{M} \times \mathrm{N}$ output matrix (Y). Using piecewise linear construction of technology, an input-oriented measure of efficiency can be calculated for the i-the beekeeping farms the solution to linear programming (LP), as follows:

$$
\begin{gathered}
\text { Minimising }_{\theta \lambda} \theta \\
\text { Subject to } \\
-y_{i}+Y_{\lambda} \geq 0 \\
\theta_{x i}-X \lambda \geq 0 \\
\lambda \geq 0 \\
\mathrm{~N} 1 \lambda=1
\end{gathered}
$$

where $\theta$ is the TE score having a value between 0 and 1 , this means that the maximum proportional reduction of all inputs is $(1-\theta)$ while holding output constant; the vector $\lambda$ is an $\mathrm{N} \times 1$ vector of weights which defines the linear combination of the peers of the $\mathrm{i}$-th beekeeping farms; $\mathrm{N} 1$ is a vector of ones and the restriction $\mathrm{N} 1 \lambda=1$ allows for variable returns to scale.

Overall technical efficiency or technical efficiency at constant return to scale (TEcrs) for each DMU, can be broken down into pure technical efficiency (technical efficiency at variable return to scale, TEvrs) and scale efficiency (SE). TEcrs does not include the portion of any inefficiency that is the result of not operating at the optimal scale. The SE of each DMU is given by the ratio TEcrs/TEvrs (17), where EE=1 indicates constant returns to scale and $E E<1$ shows scale inefficiency. SE is due to either increasing or decreasing returns to scale, which can be determined by inspecting the sum of intensity variables (9). Finally, SE quantifies the impact of scale on the productivity of a DMU. When the SE is equal to one, the constant returns to scale prevails for that DMU; and if the SE is less than one, then either increasing (IRS) or decreasing (DRS) return to scale exists.

The efficiency analysis was executed under CRS as well as VRS, as the scientific literature shows no clear preference concerning the assumptions of scale economics in beekeeping. However, some beekeeping's researchers have focused its studies on VRS specification (28).

Once the model was determined, and the level of efficiency of the beekeeping farms was

\begin{tabular}{|c|c|c|c|}
\hline $\begin{array}{l}\text { Dependents } \\
\text { variables }\end{array}$ & Apiarist's personal aspects & $\begin{array}{c}\text { Decision-making } \\
\text { process }\end{array}$ & $\begin{array}{c}\text { Technology adoption } \\
\text { level }\end{array}$ \\
\hline $\begin{array}{l}\mathrm{TE}_{\mathrm{VRS}} \\
\mathrm{TE}_{\mathrm{CRS}} \\
\mathrm{SE}\end{array}$ & $\begin{array}{l}\text { Family size (FS) } \\
\text { Age (A) } \\
\text { Experience (E) } \\
\text { Dummies } \\
\text { Civil state (CS) } \\
\text { Educational level (EL) } \\
\text { Personnel training (PT) } \\
\text { Continuity of activity (CA) } \\
\text { Primary source of family income (PSF) } \\
\text { Primary source of apiarist income (PSA) }\end{array}$ & $\begin{array}{l}\text { Dummies } \\
\text { Record (R) } \\
\text { Record use (RU) } \\
\text { Information use (IU) } \\
\text { Economic advisors (EA) } \\
\text { Technical advisors (TA) } \\
\text { Associationism (As) } \\
\text { Objective (O) } \\
\text { Planning (P) } \\
\text { Evaluation (E) }\end{array}$ & $\begin{array}{l}\% \mathrm{~T} 1 \text { Equipment area } \\
\% \mathrm{~T} 2 \text { Health area } \\
\% \mathrm{~T} 3 \text { Feeding area }\end{array}$ \\
\hline
\end{tabular}
calculated, a set of exogenous or explanatory variables were related to the efficiency scores in order to determine the causes of inefficiency. Explanatory variables used are shown in table 3 .

Table 3. Explanatory variables used in Tobit models.

Tabla 3. Variables explicativas usadas en los modelos Tobit. 
According to Ceyhan et al. (2017), the Tobit model was used to analyse the effects of management, decision-making variables and technologies adoption level affected the efficiency of beekeeping in the second stage of efficiency analysis. The standard Tobit model can be expressed as follows:

$$
\begin{gathered}
Y_{i}^{*}=\beta X_{i}+\mu_{i} ; \mu_{i} \sim\left(0, \sigma_{\mu_{i}}^{2}\right) ; i=1,2, \ldots, n \\
Y_{i}=Y_{i}^{*} \text { if } Y_{i}^{*}>0 \\
Y_{i}=1 \text { if } Y_{i}^{*} \leq 0
\end{gathered}
$$

where $Y_{i}$ is the technical efficiency score for beekeeping farms measured using a latent variable, $Y_{i}^{i}$ for positive valued and censored otherwise, $\beta$ are the parameters of the model, $X_{i}$ is a vector of explanatory variables, $\mu_{i}$ is a commonly and independently distributed error, which submits to $\mathrm{N}\left(0, \sigma_{\mu_{i}}^{2}\right)(49)$.

\section{Statistical analysis}

All the statistical analyses were carried out with software SPSS version 20 for Windows. The program used to calculate the model was DEAP Version 2.1: A Data Envelopment Analysis (Computer) Program, whose detailed operation is described in Coelli (1996). Finally, Eviews 8.0 was used to determine the canonical censored regression model, known as the Tobit.

\section{RESULTS AND DISCUSSION}

\section{Profile of the Pampean beekeeper}

Table 2 (page 154), shows the descriptive statistics for output and input variables of bee farms included in our sampling during the period 2011-2013. Research results obtained present a wide variation in all variables (inputs and output) across the different farms. The honey production, as the main output, varies from a minimum of $30 \mathrm{~kg}$ per year to a maximum of 56,000 kg per year, indicating high variability. The productivity of beekeeping is a measure of honey yield per beehive, and the honey yield is a significant factor affecting the profitability of unit production (5). A beekeeping production unit has, on average, 339.75 hives that produce an average of $13.9 \mathrm{~kg}$ of honey. Comparable results were observed by Aksoy et al. (2018) in Turkey, which obtained an average of $14 \mathrm{~kg}$ per hive in 2015. Nonetheless, higher values of productivity were found by Magaña-Magaña et al. (2016) in Mexico. According to Bragulat et al. (2018) in La Pampa there is coexistence of non-technified and small traditional with specialized models that incorporate technology achieving high productivity.

In the region of La Pampa, beekeepers have an average experience and age of 16.5 and 41.4 years, respectively. The mean family size was 2.97 individuals, with a range of 1-5. Studies carried out in Mexico, Romania, and Turkey showed similar results $(18,43,46)$. It should be noted that most beekeepers have completed at least secondary education levels and have the intention to continue pursuing their beekeeping activity (table 4, page 157). The age of the producer and his experience in the beekeeping activity are considered factors of interest for the management capacity and the adoption of new technologies. According to findings by Contreras-Escañero et al. (2013), our results suggest a low level of technological adoption (in equipment, health and feeding area) in the region of La Pampa.

\section{Technical efficiency score}

The results of the technical efficiency obtained using inputs-orientated DEA are shown in table 5 (page 158). The overall technical efficiency $\left(\mathrm{TE}_{\mathrm{CRS}}\right)$ may be decomposed into the two parts of pure technical efficiency ( $\mathrm{TE}_{\mathrm{VRS}}$ ) and scale efficiency (SE), providing some ideas about the source of inefficiency. 
Table 4. Descriptive statistics of explanatory variables to determinate of inefficiency causes.

Tabla 4. Estadística descriptiva de variables explicativas que determinan las causas de ineficiencia.

\begin{tabular}{|c|c|c|c|c|}
\hline & Mean & $\begin{array}{l}\text { Standard } \\
\text { deviation }\end{array}$ & Minimum & Maximum \\
\hline \multicolumn{5}{|c|}{ Continuous variables } \\
\hline Family size (FS) & 2.97 & 1.14 & 1 & 5 \\
\hline Age $(A)$ & 41.15 & 11.32 & 26 & 65 \\
\hline Experience (E) & 16.5 & 7.14 & 9 & 34 \\
\hline \% Equipment area (\% T1) & 54.16 & 20.23 & 16.67 & 100 \\
\hline$\%$ Health area (\% T2) & 54.64 & 19.91 & 28.57 & 100 \\
\hline$\%$ Feeding area (\% T3) & 51.5 & 24.34 & 0 & 100 \\
\hline Categorical variables & Description & Number & Percentage & \\
\hline \multirow{2}{*}{ Civil state (CS) } & 0 & 17 & 57.5 & \\
\hline & 1 & 23 & 42.5 & \\
\hline \multirow{2}{*}{ Educational level (EL) } & 0 & 7 & 17,5 & \\
\hline & 1 & 33 & 82,5 & \\
\hline \multirow{2}{*}{ Personnel training (PT) } & 0 & 22 & 55 & \\
\hline & 1 & 18 & 45 & \\
\hline \multirow{2}{*}{ Continuity of activity (CA) } & 0 & 3 & 7.5 & \\
\hline & 1 & 37 & 92.5 & \\
\hline \multirow{2}{*}{ Primary source of family income (PSF) } & 0 & 23 & 57.5 & \\
\hline & 1 & 17 & 42.5 & \\
\hline \multirow{2}{*}{ Primary source of apiarist income (PSA) } & 0 & 6 & 15 & \\
\hline & 1 & 34 & 85 & \\
\hline \multirow{2}{*}{ Record (R) } & 0 & 30 & 75 & \\
\hline & 1 & 10 & 25 & \\
\hline \multirow{2}{*}{ Record use (RU) } & 0 & 21 & 52.5 & \\
\hline & 1 & 19 & 47.5 & \\
\hline \multirow{2}{*}{ Information use (IU) } & 0 & 19 & 47.5 & \\
\hline & 1 & 21 & 52.5 & \\
\hline \multirow{2}{*}{ Economic advisors (EA) } & 0 & 34 & 85 & \\
\hline & 1 & 6 & 15 & \\
\hline \multirow{2}{*}{ Technical advisors (TA) } & 0 & 35 & 87.5 & \\
\hline & 1 & 5 & 12.5 & \\
\hline \multirow{2}{*}{ Associationism (As) } & 0 & 19 & 47.5 & \\
\hline & 1 & 21 & 52.5 & \\
\hline \multirow{2}{*}{ Objective (0) } & 0 & 21 & 52.5 & \\
\hline & 1 & 19 & 47.5 & \\
\hline \multirow{2}{*}{ Planning (P) } & 0 & 28 & 70 & \\
\hline & 1 & 12 & 30 & \\
\hline \multirow{2}{*}{ Evaluation (E) } & 0 & 23 & 57.5 & \\
\hline & 1 & 17 & 42.5 & \\
\hline
\end{tabular}


Table 5. Statistical summary of technical efficiency.

Tabla 5. Resumen estadístico de la eficiencia técnica.

\begin{tabular}{|l|c|c|c|}
\cline { 2 - 4 } \multicolumn{1}{c|}{} & $\begin{array}{c}\text { TE }_{\text {CRS }} \\
\text { Overall efficiency }\end{array}$ & $\begin{array}{c}\text { TE }_{\text {VRS }} \\
\text { Pure efficiency }\end{array}$ & $\begin{array}{c}\text { SE } \\
\text { Scale efficiency }\end{array}$ \\
\hline Mean & 0.406 & 0.572 & 0.664 \\
\hline Standard deviation & 0.002 & 0.264 & 0.346 \\
\hline Minimum & 0.03 & 0.2 & 0.05 \\
\hline Maximum & 1 & 1 & 1 \\
\hline Number of efficient DMU & 4 & 7 & 5 \\
\hline \% of firms DRS & & & 7.5 \\
\hline \% of firms IRS & & & 80 \\
\hline
\end{tabular}

The minimum and the maximum $\mathrm{TE}_{\mathrm{CRS}}$ and $\mathrm{TE}_{\mathrm{VRS}}$ scores were estimated as $0.3-1$ and $0.20-1$, respectively. These differences observed between the maximum and minimum values indicate a considerable degree of variation in the efficiency of beekeeping systems in La Pampa. On average, the overall and pure technical efficiency score of the sample of beekeeping farmers in the studied area was estimated at 0.406 and 0.572 , respectively. Our results are relatively similar to the findings of Lema and Delgado (2000) in Buenos Aires, but lower compared to Ceyhan et al. (2017) value of 0.62 from the Turkish beekeepers' association. The results indicated that bee farms in La Pampa could reduce their level of input used by approximately $42.8 \%$ assuming a variable return to scale, while maintaining the same output levels and production technologies, provided that farms adopt best-observed practices. Thus, this implies that there is quite a room for improvement.

Some farms operate either on or close to the frontier of efficiency, but a significant number of beekeeping production units show technical efficiencies below $50 \%$. Only thirteen farms and twenty-one farms have $\mathrm{TE}_{\mathrm{CRS}}$ and $\mathrm{TE}_{\mathrm{VRS}}$ over 0.50 , respectively. Our results suggest that a significant proportion of the studied bee farms have a low honey production, which is reflected in low yields, probably due to the fact that farms are operating below their optimal scale. Figure illustrates the frequency distribution of $\mathrm{TE}_{\mathrm{CRS}}$ and $\mathrm{TE}_{\mathrm{VRS}}$ in bee farms in La Pampa. Most farms showed efficiency results within the ranges 0.20 to $0.40(37.5 \%)$ and 0.40 to $0.60(40 \%)$ under CRS and VRS assumptions, respectively.

DRS ${ }^{1}$ : Decreasing returns of scale. IRS $^{2}$ : Increasing returns of scale.

DRS ${ }^{1}$ : Rendimientos decrecientes de escala.

IRS $^{2}$ : Rendimientos crecientes de escala.

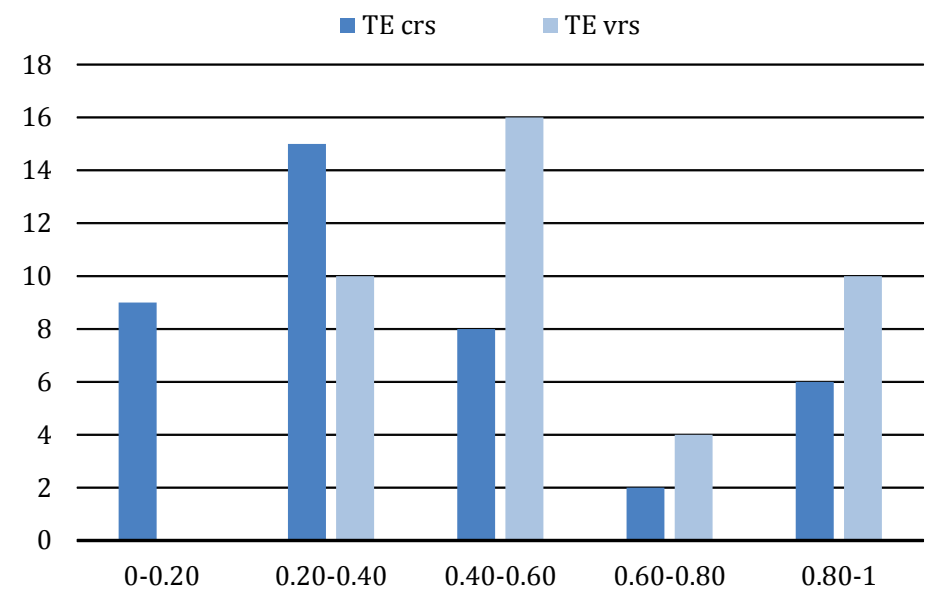

Figure 1. Frequency distribution of overall (TEcrs) and pure efficiency (TEvrs) level. Figura 1. Distribución de frecuencias del nivel de eficiencia global (TEcrs) y pura (TEvrs). 
Scale efficiency (SE) scores could be interpreted, allowing some interesting remarks. On average, the SE of the sample in the study area was estimated at 0.664 , which implies that the average size of bee farms in La Pampa is far from the optimal size. SE ( $\mathrm{TE}_{\mathrm{CRS}} / \mathrm{TE}_{\mathrm{VRS}}$ ratio) measures potential productivity gains for a farm operating at optimal scale (17). Thus, an additional $33.6 \%$ productivity gain would be feasible to provide they adjusted their farm operation to an optimal scale, close to best practices. The SE analysis provides valuable information about returns to scale; either farm is operating below or above to their optimal scale $(17,44)$. Overall, $7.5 \%$ were operating under decreasing return scale (DRS), and most scale-inefficient farms (80\%) displayed were operating under increasing returns scale (IRS). This implies an opportunity to gain additional honey production through carefully planned growth. This finding is consistent with the results reported in American beekeeping by Jones-Ritten et al. (2018).

The efficiency analysis of Pampean apiculture farms suggests that the latter are small farms that need to increase their size, in order to achieve best practice's level (table 6). Our findings are consistent with the overall picture of the Buenos Aires bee farms showed by Lema and Delgado (2000). They reported that several hives given as size indicator, affected the productivity of farms, and probably this will imply a negative effect on economic performance.

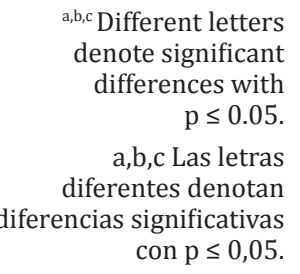

denote significant differences with $\leq 0.05$. rentes denotan con $\mathrm{p} \leq 0,05$.
Table 6. Farm size (in number of hives) according to return to scale.

Tabla 6. Tamaño de las explotaciones de acuerdo con su rendimiento de escala.

\begin{tabular}{|l|c|c|c|}
\hline \multicolumn{1}{|c|}{ Returns of scale } & Farms (\%) & Mean & Standard Deviation \\
\hline Decreasing returns of scale & 7.5 & $1766.67^{\mathrm{c}}$ & 1766,67 \\
\hline Increasing returns of scale & 80 & $197.18^{\mathrm{a}}$ & 172,327 \\
\hline Constant returns of scale & 12.5 & $1100^{\mathrm{b}}$ & 839,643 \\
\hline
\end{tabular}

\section{The second stage: determinants of technical efficiency}

The effects of influencing factors on inefficiency showed in table 3 (page 155), are evaluated by using the Tobit model. The results of the regression analysis are shown in table 7 (page 160).

Assuming variables scale returns model how the best fit (Log-likelihood = 18.568; AIC $=0.260$ ), the crucial determinants that positively affected to technical efficiency in bee farms in La Pampa were civil state (married), educational level, the primary source of family and apiarist income, information usage, planning and health area. On the other hand, personnel training, continuity of activity and objective affected negatively on $\mathrm{TE}_{\mathrm{CRS}}(\mathrm{p}<0.05)$.

Regarding manager personal aspects, it can be highlighted that, contrary to what was expected, both experience and age did not affect technical efficiency These variables are aspects that are usually considered always in the management and decision-making in the company, but are also found to be very controversial (39). The explanation for this is probably the low average technical efficiency score and the sample size. On the other hand, results obtained also show how the marital status (married) positively affects the efficiency level, what highlights the vital role that women play in beekeeping and the rural areas $(42,43)$. The fact that families have apiculture as the primary source of income was also positively associated, which may be linked to a higher level of innovation and adoption of technology that could favour the development of the beekeeping activity (10).

In terms of the aspects related to access and use of information and formality of the decision-making process, the use of external information, as well as setting objectives and appropriate planning, have a positive impact on the efficiency score. These results agree with the works of Mujuni et al. (2012) in Uganda and Adgaba et al. (2014) in Saudi Arabia.

Regarding technologies adoption level, only health area had a positive effect on technical efficiency. It is understood that those apicultural units that adopt a more significant number of health items also make management more efficient. Our findings are in complete agreement with Ferrier et al. (2018) which suggested that the livelihood of beekeepers depends on the health and productivity of his apiaries. In this way, it would be crucial to identify those beekeeping units that carry out the best practices and detect critical points by applying benchmarking techniques $(25,28)$. 
Table 7. Results of the Tobit analysis: technical inefficiency determinants.

Tabla 7. Resultados del análisis de Tobit: determinantes de la ineficiencia técnica.

\begin{tabular}{|c|c|c|c|c|c|c|c|}
\hline & \multirow{2}{*}{ Variable } & \multicolumn{2}{|c|}{$\mathrm{TE}_{\mathrm{CRS}}$} & \multicolumn{2}{|c|}{$\mathrm{TE}_{\mathrm{VRS}}$} & \multicolumn{2}{|c|}{ SE } \\
\hline & & Coefficient & $\mathbf{P}$ & Coefficient & $\mathbf{P}$ & Coefficient & $\mathbf{P}$ \\
\hline & Constant & -0.992720 & 0.0943 & 0.086719 & 0.8768 & -0.305242 & 0.7001 \\
\hline & Family size (FS) & 0.015141 & 0.7069 & -0.028394 & 0.4544 & 0.004818 & 0.9286 \\
\hline & Civil state (CS) & -0.036462 & 0.7911 & 0.259462 & 0.0455 & -0.207605 & 0.2589 \\
\hline & Age (A) & 0.022020 & 0.0361 & -0.001898 & 0.8480 & 0.025055 & 0.0742 \\
\hline & Experience (E) & -0.020177 & 0.0164 & -0.005866 & 0.4592 & -0.019351 & 0.0849 \\
\hline & Educational level (EL) & 0.166749 & 0.2657 & 0.282259 & 0.0456 & -0.117131 & 0.5583 \\
\hline & Personnel training (PT) & -0.330231 & 0.0007 & -0.192362 & 0.0369 & -0.196430 & 0.1327 \\
\hline & Continuity of activity (CA) & -0.146536 & 0.3791 & -0.442170 & 0.0049 & -0.014255 & 0.9489 \\
\hline & Primary source of family income (PSF) & 0.020374 & 0.7843 & 0.210233 & 0.0027 & -0.097165 & 0.3286 \\
\hline & Primary source of apiarist income (PSA) & 0.134705 & 0.3134 & 0.176255 & 0.1617 & -0.118791 & 0.5057 \\
\hline & Record (R) & -0.163369 & 0.2055 & -0.071772 & 0.5551 & -0.142141 & 0.4096 \\
\hline & Record use (RU) & -0.296037 & 0.0570 & -0.292748 & 0.3700 & -0.160594 & 0.2615 \\
\hline & Information use (IU) & 0.414225 & 0.0000 & 0.387486 & 0.0000 & 0.364925 & 0.0066 \\
\hline & Economic advisors (EA) & -0.591872 & 0.0017 & -0.286902 & 0.1066 & -0.374265 & 0.1375 \\
\hline & Technical advisors (TA) & 0.185498 & 0.1851 & 0.070671 & 0.5922 & 0.053399 & 0.7752 \\
\hline & Associationism (As) & -0.141698 & 0.1512 & -0.103677 & 0.2652 & -0.249247 & 0.0587 \\
\hline & Objective $(0)$ & -0.199455 & 0.0454 & -0.288988 & 0.0021 & -0.115305 & 0.3866 \\
\hline \multirow{4}{*}{$\begin{array}{r}\mathrm{TE}_{\mathrm{CRS}}=\text { Overall technical } \\
\text { efficiency; } \mathrm{TE}_{\mathrm{VRS}}=\text { pure } \\
\text { technical efficiency; } \\
\mathrm{SE}=\text { scale efficiency. }\end{array}$} & Planning $(\mathrm{P})$ & 0.554160 & 0.0007 & 0.370894 & 0.0156 & 0.490463 & 0.0241 \\
\hline & Evaluation (E) & 0.209191 & 0.0313 & 0.120220 & 0.1892 & 0.173326 & 0.1817 \\
\hline & Equipment area (\% T1) & -0.002354 & 0.2672 & -0.001463 & 0.4645 & 0.000344 & 0.9033 \\
\hline & Health area (\% T2) & 0.013947 & 0.0000 & 0.011399 & 0.0000 & 0.009562 & 0.0011 \\
\hline \multirow{4}{*}{$\begin{array}{r}\text { TE CRS = Eficiencia } \\
\text { técnica media } \\
\text { TE VRS = Eficiencia } \\
\text { técnica pura } \\
\text { Eficiencia de escala. }\end{array}$} & Feeding area (\% T3) & 0.002906 & 0.1594 & 0.001913 & 0.3258 & 0.002546 & 0.3563 \\
\hline & Log likelihood & 16.557 & & 18.568 & & 6.711 & \\
\hline & Avg. Log likelihood & 0.486 & & 0.546 & & 0.197 & \\
\hline & Akaike info criterion & 0.379 & & 0.260 & & 0.958 & \\
\hline
\end{tabular}

According to table 7, the most important variables that positively affected SE were information use, planning and health area. The results of our study suggest that lower units of production might improve the SE by adopting technologies, particularly in the area of management and health. Usually, the adoption of technologies is associated with a better organizational structure, which occurs in larger production units. The importance of size, in several hives, was confirmed as the decisive variable for the improvement of scale efficiency (table 6, page 159). Similar results were obtained in apicultural units from Buenos Aires (30).

Although this method used a robust methodology to calculate technical efficiency scores and a checked regression approach, the small sample size likely limited our ability to identify the more statistically significant variable. Future studies should include an emphasize on getting larger samples of productions units from different locations, to understand better the roles of management factors $(11,28,50)$.

\section{POLICY IMPLICATION AND CONCLUSIONS}

On average, bee farmers in La Pampa (Argentina) are operating below the production frontier, which indicates there is still scope for improvement. Beekeepers have greater control over their inputs that outputs, thus the input orientated model was used. The scale of the bee farms in La Pampa does not reach the optimal levels required to achieve productive efficiency, and it would be convenient to increase their scale.

The government should promote to help inefficient bee farms in order to achieve their best practice by assuming benchmarking techniques. Beekeepers should also be motivated by the government to improve their efficiency through incentives, such as training programs to ease decision-making and management, therefore enhancing productivity. 
Most of the explanatory variables in the Tobit model have expected sign but statistically insignificant. Despite these limitations and the sample size, our study has contributed to the existing literature on studies of technical efficiency in bee farms. However, more definite conclusions will be possible when additional studies focus on further analysis of heterogeneous production frontiers (according to size or location) and the quantification of total slacks in inputs set by applying benchmarking techniques.

\section{REFERENCES}

1. Adgaba, N.; Al-Ghamdi, A.; Shenkute, A. G.; Ismaiel, S.; Al-Kahtani, S.; Tadess, Y.; Adebe, W. 2014. Socio-economic analysis of beekeeping and determinants of box hive technology adoption in the Kingdom of Saudi Arabia. Journal of Animal and Plant Sciences. 24(6): 1876-1884.

2. Affognon, H. D.; Kingori, W. S.; Omondi, A. I.; Diiro, M. G.; Muriithi, B. W.; Makau, S.; Raina, S. K. 2015. Adoption of modern beekeeping and its impact on honey production in the former Mwingi District of Kenya: assessment using theory-based impact evaluation approach. International Journal of Tropical Insect Science. 35(2): 96-102.

3. Agera, S. I. N. 2011. Role of beekeeping in the conservation of forests. Global Journal of Agricultural Sciences. 10(1): 27.

4. Aksoy, A.; Ertürk, Y. E.; Erdoğan, S.; Eyduran, E.; Tariq, M. M. 2018. Estimation of honey production in beekeeping enterprises from Eastern part of Turkey through some data mining algorithms. Pakistan Journal of Zoology. 50(6).

5. Al-Ghamdi, A. A.; Adgaba, N.; Herab, A. H.; Ansari, M. J. 2017. Comparative analysis of profitability of honey production using traditional and box hives. Saudi Journal of Biological Sciences. 24(5): 1075-1080.

6. Angón, E.; García, A.; Perea, J.; Acero, R.; Toro-Mújica, P.; Pacheco, H.; González, A. 2013. Eficiencia técnica y viabilidad de los sistemas de pastoreo de vacunos de leche en La Pampa, Argentina. Agrociencia. 47(5): 443-456.

7. Angón, E.; Perea, J.; Toro-Mújica, P.; Rivas, J.; de-Pablos, C.; García, A. 2015. Pathways towards to improve the feasibility of dairy pastoral system in La Pampa (Argentine). Italian Journal of Animal Science. 14(4): 3624.

8. Areal, F. J.; Tiffin, R.; Balcombe, K. 2012. Farm technical efficiency under a tradable milk quota system. Journal of Dairy Science. 95(1): 50-62.

9. Banker, R. D.; Charnes, A.; Cooper, W. W. 1984. Some models for estimating technical and scale inefficiencies in data envelopment analysis. Management science. 30(9): 1078-1092.

10. Bragulat, T.; Angón, E.; García, A.; Giorgis, A.; Barba, C.; Perea, J. 2018. Influencia de la capacidad gerencial del apicultor en la viabilidad de unidades de producción apícola en la Pampa Argentina. Revista Mexicana de Ciencias Pecuarias. 9(1): 32-47.

11. Carmona Crocco, J.; Greco, S.; Tapia, R.; Martinelli, M. 2019. Use of indicators as a tool to measure sustainability in agroecosystems of arid land, San Juan, Argentina. Revista de la Facultad de Ciencias Agrarias. Universidad Nacional de Cuyo. Mendoza. Argentina. 52(1): 190-209.

12. Ceyhan, V.; Canan, S.; Yıldırım, Ç.; Türkten, H. 2017. Economic structure and services efficiency of Turkish Beekeepers' Association. European Journal of sustainable development. 6(4): 53-64.

13. Chang, H. H.; Mishra, A. K. 2011. Does the milk income loss contract program improve the technical efficiency of US dairy farms? Journal of Dairy Science. 94(6): 2945-2951.

14. Charnes, A.; Cooper, W. W.; Rhodes, E. 1978. Measuring the efficiency of decision-making units. European Journal of operational research. 2(6): 429-444.

15. Chavas, J. P.; Petrie, R.; Roth, M. 2005. Farm household production efficiency: Evidence from the Gambia. American Journal of Agricultural Economics. 87: 160-179.

16. Coelli, T. 1996. A guide to DEAP version 2.1: a data envelopment analysis (computer) program. Centre for Efficiency and Productivity Analysis, University of New England. Australia.

17. Coelli, T. J.; Rao, D. S. P.; O’Donnell, C. J.; Battese, G. E. 2005. An introduction to efficiency and productivity analysis. Springer Science \& Business Media.

18. Contreras-Escareño, F.; Pérez-Armendáriz, B.; Echazarreta, C. M.; Cavazos-Arroyo, J.; MacíasMacías, J. O.; Tapia-González, J. M. 2013. Características y situación actual de la apicultura en las regiones Sur y Sureste de Jalisco, México. Revista Mexicana de Ciencias Pecuarias. 4(3): 387-398.

19. Cooper, W.; Seiford, L.; Zhu, J. 2011. Handbook on data envelopment analysis. vol. 164. Springer. Boston. Mass. USA.

20. FAO. 2018. Our Priorities. The FAO Strategic Objectives. http://www.fao.org/3/I8580EN/i8580en. pdf. (Consultado el 11 mar, 19).

21. FAOSTAT. 2018. Organización de las Naciones Unidas para la Agricultura y la Alimentación. http:// faostat.fao.org/site/339/default.aspx. (Consultado 25 Nov, 2018). 
22. Farrell, M. J. 1957. The measurement of productive efficiency. Journal of the Royal Statistical Society: Series A (General). 120(3): 253-281.

23. Ferrier, P. M.; Rucker, R. R.; Thurman, W. N.; Burgett, M. 2018. Economic effects and responses to changes in honey bee health (No. 1477-2018-5465).

24. Freitas, D. F. F.; Khan, A. S.; Silva, L. M. R. 2004. Nivel tecnológico e rentabilidad de produçao de mel de abelha (Apis mellifera) no Ceará. RER. Rio de Janeiro. 42: 171-188.

25. Formato, G.; Smulders, F. J. 2011. La gestión del riesgo en la producción apícola primaria. Parte 1: salud de las abejas y prevención de enfermedades y mejores prácticas asociadas. Veterinaria trimestral. 31 (1): 29-47.

26. García-Martínez, A.; Rivas-Rangel, J.; Rangel-Quintos, J.; Espinosa, J. A.; Barba, C.; De-Pablos Heredero C. 2016. A methodological approach to evaluate livestock innovations on small-scale farms in developing countries. Future Internet. 8(2):25.

27. Giorgis, A. 1994. Plan de desarrollo del este de la provincia de La Pampa. Ministerio de La Producción de La Pampa Ed. Santa Rosa. Argentina. 25-27.

28. Jones-Ritten, C.; Peck, D.; Ehmke, M.; Patalee, M. B. 2018. Firm efficiency and returns-to-scale in the honey bee pollination services industry. Journal of Economic Entomology. 111(3): 1014-1022.

29. Latruffe, L.; Balcombe, K.; Davidova, S.; Zawalinska, K. 2004. Determinants of technical efficiency of crop and livestock farms in Poland. Applied Economics. 36: 1255-1263.

30. Lema, D.; Delgado, G. 2000. Productividad y fuentes de eficiencia técnica en apicultura: estimación de fronteras estocásticas de producción con datos de panel. http://inta.gob. ar/documentos/productividad-y-fuentes-de-eficiencia-tecnica-en-apicultura-estimacionde-fronterasestocasticas-de-produccion-con-datos-de-panel/at_multi_download/file/ apicultura.pdf.

31. Magaña-Magaña, M. A.; Tavera-Cortés, M. E.; Salazar-Barrientos, L. L.; Sanginés-García, J. R. 2016. Productividad de la apicultura en México y su impacto sobre la rentabilidad. Revista mexicana de ciencias agrícolas. 7(5): 1103-1115.

32. Magaña-Magaña, M. A.; Sanginés-García, J. R.; Lara y Lara, P. E.; Salazar-Barrientos, L.; Leyva Morales, C. E. 2017. Competitividad y participación de la miel mexicana en el mercado mundial. Revista Mexicana de Ciencias Pecuaria. 8(1): 43-52.

33. Makri, P.; Papanagiotou, P.; Papanagiotou, E. 2015. Efficiency and economic analysis of Greek beekeeping farms. Bulgarian Journal of Agricultural Science. 21(3): 479-484.

34. Maseda, F.; Diaz, F.; Alvarez, C. 2004. Family dairy farms in Galicia (NW Spain): classification by some family and farm factors relevant to quality of life. Biosystems Engineering. 87(4): 509-521.

35. Milán, M. J.; Caja, G.; González-González, R.; Fernández-Pérez, A. M.; Such, X. 2011. Structure and performance of Awassi and Assaf dairy sheep farms in northwestern Spain. Journal of Dairy Science. 94(2): 771-784.

36. Morantes, M.; Dios-Palomares, R.; Peña, M. E.; Rivas, J.; Angón, E.; Perea, J.; García-Martínez, A. 2014. Incidencia de las características del ganadero en su labor gerencial: un estudio en los sistemas de producción con ovinos de leche en Castilla-La Mancha. España. Revista Científica. 24(3).

37. Mujuni, A.; Natukunda, K.; Kugonza, D. 2012. Factors affecting the adoption of beekeeping and associated technologies in Bushenyi District, Western Uganda. Livestock Research for Rural Development. 24(8).

38. Noguera-Talavera, Á.; Salmerón, F.; Reyes-Sánchez, N. 2019. Bases teórico-metodológicas para el diseño de sistemas agroecológicos. Revista de la Facultad de Ciencias Agrarias. Universidad Nacional de Cuyo. Mendoza. Argentina. 51(1): 273-293.

39. Perea, J.; de Pablos-Heredero, C.; Angón, E.; Giorigs, A.; García, C.; Barba, C. 2014. Using farmer decision-making profiles and managerial capacity as predictors of farm viability in Argentinean dairy farms (La Pampa). Revista Científica FCV-LUZ. (24): 509-517.

40. Perea-Muñoz, J. M.; Giorgis, A.; García Martínez, A.; Larrea, Á.; Gómez Castro, A. G.; Mata, H. 2011. Estructura de las explotaciones lecheras de La Pampa (Argentina). Revista Científica. 21(3).

41. Perrigot, R.; Barros, C. P. 2008. Technical efficiency of French retailers. Journal of Retailing and Consumer Services. 15(4): 296-305.

42. Pocol, C. B.; Ilea, M.; Popa, A. A. Economic diagnosis of beekeeping in the North West region of Romania: a case study of Cluj county. Analele UniversitãÑii din Oradea, Fascicula: Ecotoxicologie, Zootehnie si Tehnologii de Industrie Alimentarã 2011. (10): 279-286.

43. Pocol, C. B. 2011. Sustainable policies for the development of beekeeping in Romania. Zeszyty Naukowe Szkoły Głównej Gospodarstwa Wiejskiego w Warszawie. Problemy Rolnictwa Światowego. 11(3).

44. Read, L.; Thanassoulis, E. 2010. Improving the identification of returns to scale in Data Envelopment Analysis Journal of the Operational Research Society. 51(2000): 102-110.

45. Registro nacional de productores apícolas. 2017. Ministerio de Agroindustria, Presidencia de la Nación. https://renapa.magyp.gob.ar/. (Consultado 20 oct. 2018).

46. Saner, G.; Engindeniz, S.; Tolon, B.; Cukur, F. 2004. The economic analysis of beekeeping enterprise in sustainable development: A case study of Turkey. Apiacta. 38: 34-35. 
47. SENASA. Indicadores ganaderos. Existencias bovinas por categorías y departamento. 2017. http://www.senasa.gob.ar/cadena-animal/bovinos-y-bubalinos/informacion/ informesy-estadisticas

48. Solano, C.; León, H.; Pérez, E.; Tole, L.; Fawcett, R. H.; Herrero, M. 2006. Using farmer decision-making profiles and managerial capacity as predictors of farm management and performance in Costa Rican dairy farms. Agricultural Systems. 88(2-3): 395-428.

49. Tobin, J. 1958. Estimation of relationships for limited dependent variables. Econometrica: Journal of the Econometric Society. 24-36.

50. Tonolli, A. J. 2019. Propuesta metodológica para la obtención de indicadores de sustentabilidad de agroecosistemas desde un enfoque multidimensional y sistémico. Revista de la Facultad de Ciencias Agrarias. Universidad Nacional de Cuyo. Mendoza. Argentina. 51(2): 381-399.

51. Toro-Mujica, P.; García, A.; Gómez-Castro, A. G.; Acero, R.; Perea, J.; Rodríguez-Estévez, V.; Aguilar, C.; Vera, R. 2011. Technical efficiency and viability of organic dairy sheep farming systems in a traditional area for sheep production in Spain. Small Ruminant Research. 100(2-3): 89-95.

52. Toro-Mujica, P.; García, A.; Aguilar, C.; Vera, R.; Perea, J.; Angón, E. 2015. Economic sustainability of organic dairy sheep systems in Central Spain. Italian Journal of Animal Science. 14(2): 3625.

53. Wilson, P.; Hadley, D.; Asby, C. 2001. The influence of management characteristics on the technical efficiency of wheat farmers in eastern England. Agricultural Economics. 24(3): 329-338. 